\title{
Marginalisation of the Dan fishing community and relocation of Sanya fishing port, Hainan Island, China
}

\author{
Zuan Ou \\ Sun Yat-sen University, Guangzhou, Guangdong Province, China \\ Sanya University, Sanya, Hainan Province, China \\ ouzuan@mail3.sysu.edu.cn
}

and

Guoqing Ma

Minzu University of China, Beijing, China

hssmgq@mail.sysu.edu.cn

\begin{abstract}
When marginal groups face social transformation, they risk being unable to adapt and acquire equal developmental opportunities, slipping into 'further marginalisation'. This paper explores the case of the Dan fishing community of Sanya City, Hainan, China. Efforts to transform Sanya City into an international island tourism destination involve plans to relocate Sanya fishing port and to clear the adjacent neighbourhood inhabited by the Dan people, traditionally a boat-dwelling people, who have long been marginalised relative to China's land-oriented society. As their natural and social resources dwindle, the Dan of Sanya City must cope with the loss of their homes and livelihoods, as they are forced into the city's suburbs and as the port relocation complicates the economics and practicalities of making a living from the fishing industry. This paper argues for greater attention to be given to local needs in the formulation of urban development strategies in island cities.
\end{abstract}

Keywords: Dan people, fishing community, Hainan, island cities, island tourism, marginalisation

https://doi.org/10.24043/isj.32

(C) 2017 — Institute of Island Studies, University of Prince Edward Island, Canada.

\section{Introduction}

This paper considers how urban renewal and port relocation in Sanya, Hainan is causing the 'further marginalisation' of the island city's Dan fisherfolk. 'Further marginalisation' is a process in which already marginal groups risk being unable to adapt to wider social transformations and thereby lose out on opportunities for development.

Dan people 疍民 are one of the most characteristic marine groups in China. On the island of Hainan, the Dan - an ethnic group that traditionally lived aboard their fishing boats - moved ashore and helped establish what is today's Sanya Port over the course of the 20th Century. However, as Hainan becomes increasingly urbanised and as Sanya City transitions into an international tourism destination, Sanya Port is being redeveloped, and the fishing port is being relocated outside the city. This is threatening the culture, homes, and livelihoods of the local Dan fisherfolk. The problems facing the Dan of Sanya City differ from those confronting many marginalised peoples on the Chinese mainland, both because of Sanya's status as an island city and because the Dan's maritime livelihoods have disadvantaged them in an era of urbanisation.

This paper is grounded in enthographic fieldwork, participant observation, and surveys that Zuan Ou conducted in Sanya City and Yazhou Bay 崖州湾 between 2012 and 2017, focusing on the transformation and development of the city's fishing port and its surrounding fishing community during this period. At the core of the fieldwork are open-ended interviews 
conducted with 41 members of the Dan community, leading to Zuan Ou maintaining close contact with five Dan families. The interviews investigated the history and present-day lives of the Dan as well as discussed issues arising from the redevelopment of the Shuijuxiang neighbourhood and the relocation of Sanya's fishing harbour. As with all communities, the Dan do not possess uniform opinions or a monolithic outlook, and individuals have their own distinctive hopes, criticisms, and understandings of their community.

This new research is important because the Dan of Sanya have been subject to very little previous dedicated research, with the most prominent example being the anthropogeographical studies undertaken by Zeng Zhaoxuan (曾昭璇, 1988) in the 1980s. Research into the Dan more broadly has mostly concentrated on their ethnic origins, identity, social discrimination, and folk culture (黄向春, 2008). The present paper is an attempt both to highlight socioeconomic aspects of the lives of urbanised Dan and to consider the results of changing economic focus and urban renewal in an island city. Whereas another paper based on this research (Grydehøj \& Ou, 2017) focuses on connections between Sanya City's urban renewal and issues associated with indigeneity, the present paper instead interprets the plight of the Dan in terms of societal marginalisation.

We first discuss Sanya City's historical development, particularly in light of island studies. We then describe the efforts to relocate Sanya's fishing port. This is followed by a discussion of societal marginalisation and further marginalisation in both Chinese and Western scholarship, with reference to the Dan fisherfolk.

\section{Hainan's movement periphery to centre}

The island of Hainan has long been regarded as uncivilised. In the Tang Dynasties (618-907) and Song Dynasties (960-1279), Yazhou (today's Sanya region) was the place of farthest exile for officials of the central dynasty and was known as 'the remotest corner of the globe' (杨其元, 2008). Among the well-known officials who were exiled to Hainan was the poet Su Shi, who said of Hainan: "In the vast region of Qiongya, a stone stands in the sea. The Han nation has lived with the minorities and related with them since long ago 琼崖千里环海中，民夷错居古相蒙” (苏轱, 2005, p. 3975).

By the standards of the mainland empire, Hainan was a remote periphery, largely beyond the reach of the central government. The island's isolation from the mainland conditioned the presence and interaction of the various ethnic groups that made it their home, with Li, Miao, Hui, Dan, and Han communities contributing to a distinctive sociocultural system. This isolation furthermore determined the degree, manner, and approach of migration to and from the island as well as the extent and means of cultural transmission. South China itself was peripheral to the central dynasty, and although the Qiongzhou Strait separates Hainan from the mainland by a distance of just $22 \mathrm{~km}$, the island's large size $\left(35,400 \mathrm{~km}^{2}\right)$ meant that it hosted a mix of terrestrial, coastal, and marine cultures and that it functioned as a relatively closed space.

The largest population centre in today's Hainan is Haikou (2010 population: 2,046,189; 海口市统计信息网, 2011), centred around the mouth of the Nandu River. The second-largest population centre is Sanya (2015 population: 577,820; 三亚统计信息网, 2016), centred around the mouth of the Sanya River. These two port cities are Hainan's major economic hubs. In addition to being cities on the large island of Hainan, Haikou and Sanya are also 'island cities' in the sense that they are both "substantially or significantly located on one or more densely urbanised small islands" (Grydehøj et al., 2015), in this case the river delta islands from which the cities arose. As Sheng et al. (2017) note, because of the importance of island spatiality for urbanisation processes and because of the prominence of island cities within China's urban networks, "spatially and historically sensitive geographical understandings of island city development are necessary if we are to understand Chinese urbanisation more broadly."

Sanya is today a city of national importance due to its promotion as a site for international 
tourism. Hainan's tourism industry developed along the island's east coast and has extended into its mountainous interior. The lure of tourism income and real estate led development, however, has prompted the removal of residents living along the coasts and the allocation of this cleared land to developers, resulting in significant changes in land-use patterns (Wang \& Liu, 2013). The resultant coastal urbanisation has been complemented by government initiatives to increase industrialisation. By 2014, the island, which had until recently been primarily rural, had reached an urbanisation rate of $53.76 \%$ (海南省政府, 2015). Sanya City, with an area of $1919.58 \mathrm{~km}^{2}$, is the only large-scale tropical coastal city in China's southern waters.

\section{Long-term development policies}

Over the past century, the central government has designed three major development plans for Hainan. The first was carried out between 1927 to 1937, a golden decade for the government of the time. The powerful politician and businessman Tse-ven Soong 宋子文 even visited Hainan to participate in formulating the development plan. Xisha (the Paracel Islands) were also included in the scope of this plan, but the start of the Sino-Japanese War (1937-1945) interrupted these development activities. The second major development plan was formulated in 1988, when Hainan was separated from Guangdong and became a province in its own right. Problems involving criminality (such as car smuggling) and a property bubble, however, hindered any breakthrough for Hainan's economy. The third development plan was launched at the end of 2009, when the central government decided to promote Hainan as an international tourism island. The island's tourism development heated up rapidly.

The state has a history of devising long-term development plans, which have not, however, always dedicated sufficient attention to the localised impacts of their pursuit of strategic objectives. For example, the introduction of rubber plantations and the establishment of state farms in the 1950s led to a single-crop agricultural economy, the negative effects of which continue to reverberate in the island's society. Then, in the 1980s, a 20-year plan was proposed with the aim of bringing Hainan up to Taiwan's developmental standards.

In recent years, marine resources and environmental protection have become more prominent in Chinese policymaking, resulting in a national policy goal of constructing an 'ecological civilisation' (Zhang Xiaohong et al., 2016). The central government's 'One Belt, One Road' initiative (Du, 2016) has likewise placed unprecedented attention on China's fisherfolk. Policymakers, however, have neglected local needs on Hainan, focusing instead on national objectives. An attempt was made to use Hainan as a laboratory for experimenting with the elimination of poverty, though this ended up being little more than wishful thinking (容观瓊, 1991). Hainan, for instance, was designated as one of China's first four special economic zones, which were all located in island and/or river delta environments. Hainan has also been regarded as China's "laboratory for anthropological research" (麻国庆, 2014), a perspective from which Sanya Port represents the site of a crucially important cultural and policy experiment. This follows an international tendency to treat islands as 'novelty sites' for social, economic, and political experimentation (Baldacchino, 2007, 2012). One difficulty with such experimentation that is driven by higherlevel authorities is that it might not be designed to fulfil local needs or target local problems.

Partially because of these development policies, Hainan is transforming from a relatively closed space to an extremely open space, and its cities are transforming to serve new social and economic needs. The process of urban renewal and reconstruction, however, affects local society and has the potential to spark social problems. The task is to ensure a harmonious balance between repurposing urban space and reconstructing urban cultures. Local residents are the main stakeholders in urban development, and it is vital to protect their interests and prevent their being pushed to the margins of society. In short, it is necessary to construct equitable urban social space. 


\section{Development and relocation of Sanya Port}

Generally speaking, urban coastal development can take one of two main directions. One possibility is external spatial development, through the expansion of the city into its terrestrial hinterlands or into the sea via land reclamation (Grydehøj, 2015). The other possibility is the reconstruction of the city's internal space. Sanya is located in a hilly environment, and the northern portion of the city is mountainous. As such, its most important spatial resource is coastal land and offshore and riverine islands. Developmental focus has thus rested on reconstructing the city's downtown coastal area, especially on reconstructing the city's port area. The repurposing of city centre waterfronts into tourism and leisure zones is a common phenomenon, both elsewhere in China (e.g. 陈永锭, 2013; Hong, 2017) and abroad, but the effects of this displacement of existing urban functions may be particularly strong in island cities in which urban expansion into the interior is difficult.

Sanya Port (formerly called Linchuan Port) was a famous South China salt and fishing port in ancient times. In the Ming Dynasty (1368-1644), it became an intermediate port for tribute boats by virtue of its relative proximity to the Southeast Asian states under China's sphere of influence (三亚新闻网, 2013). In the sixth year of the reign of Qing Emperor Yongzheng 雍正帝 (1728), the port's name was changed to Sanya. When the Japanese invaded Hainan in February 1939, they made Sanya their naval base, a status it held until August 1945. In 1953, Sanya Port was transformed into a commercial port and performed most of the passenger and freight transport functions for eastern and southern Hainan. Since 1980, Sanya Port has attracted boats from Guangdong, Guangxi, Hong Kong, Macau, and Taiwan, serving not only as a port for trade but also as a place to acquire supplies and find shelter from inclement weather. It gradually developed into a comprehensive port, integrating Sanya's passenger transport, cargo transport, fishing port (see Figure 1), and tourism functions. It became the largest multipurpose port in the south of Hainan.

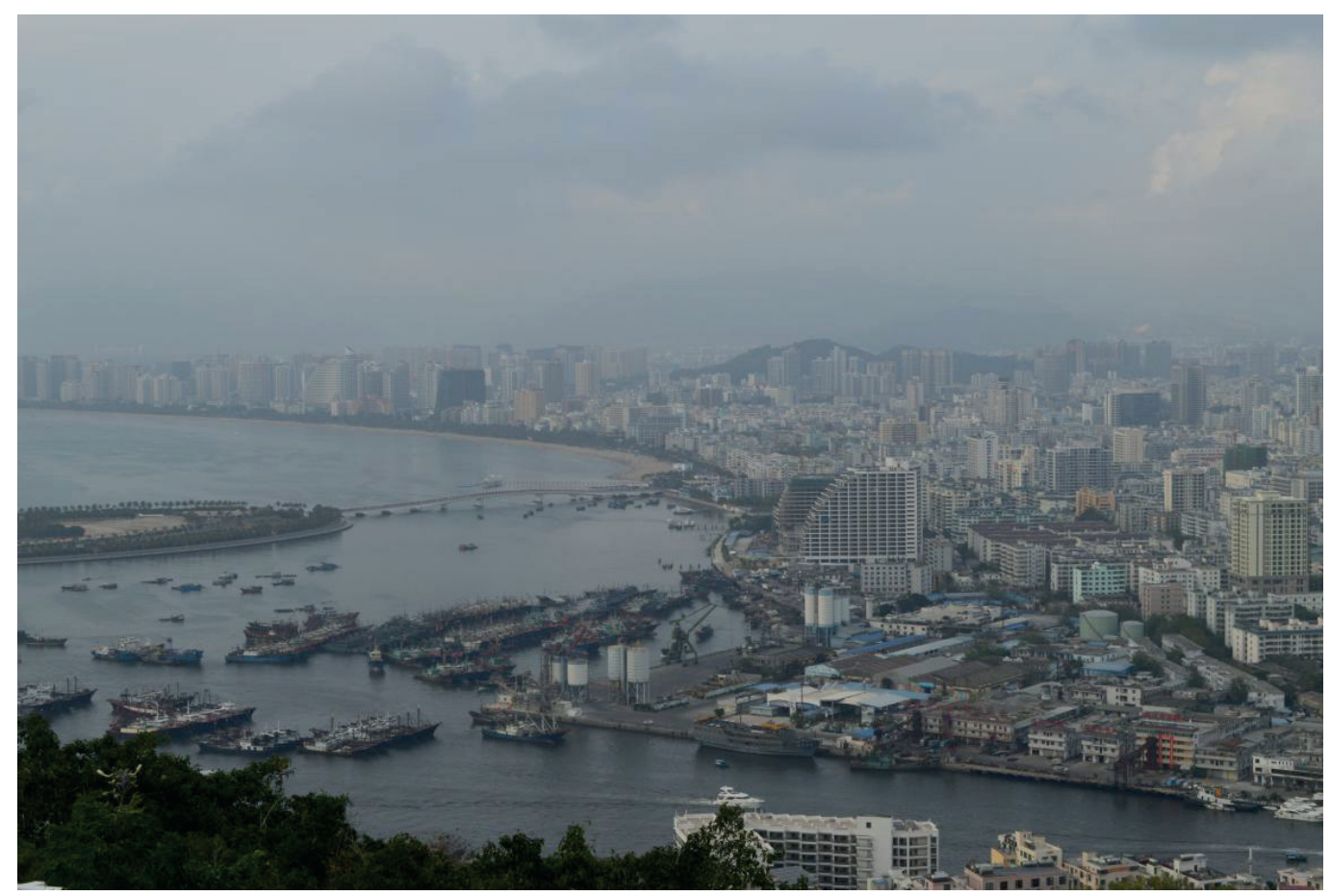

Figure 1: The old Sanya fishing port (Source: (C) Zuan Ou, 2015).

Although Hainan has historically been distant from centres of political power, it has long attracted immigrants. Among the early settlers of Sanya Port and its hinterlands were fisherfolk from Guangdong, Guangxi, and Fujian, intermingled with migrants from Ledong 乐东, Danzhou 儋州, Lingao 临高, Wenchang 文昌, and elsewhere on the island. These immigrants 
made the port their home and source of livelihood. River delta islands possess spatial benefits that make them ideal for port functions, while limited land availability encourages the formation of highly dense urban centres on such port city islands (Grydehøj, 2015). This is precisely what has happened around Sanya Port. In recent years, there has been growing governmental concern about conditions at the port: a rapidly increasing number of boats has led to a lack of berths and serious water pollution. This, combined with a wider desire to upgrade and renew the city centre, led to a government proposal to split up Sanya Port's primary functions (fishing, international passenger transport, cargo, and yachting tourism) into separate ports. As part of this plan, the existing Sanya Port would be given over exclusively to high-end tourism and yachting. An International Cruise Terminal has been established on the artificial island of Baipai 白排人工岛. The container port has been relocated outside of Hainan completely in an effort to concentrate cargo container functions in Nanshan. The present paper focuses on the efforts, launched in 2008, to relocate the fishing port from Sanya Port to Ningyuan River Estuary 宁远河口 in Yazhou Bay.

Relocation of the fishing port has proved especially difficult. Sanya Port is located in a natural harbour. Not only does it bring together local fisherfolk (mainly of the Dan ethnic group), but it also gathers fisherfolk from other counties, seeking to benefit from the economies of scale derived from the port's production operations. Yugang Community 榆港社区 and Nanhai Community 南海社区, inhabited by the Dan, belong to the Tianya District of Sanya City, a district currently holding 2,100 fisherfolk households, comprised of 9,620 fishermen, 5,800 fishing labourers, and 603 fishing vessels of various kinds (三亚市天涯区人民政府, 2016). These communities' two fishing cooperatives, Yufeng Cooperative 榆丰合作社 and Haiyu Cooperative 海榆合作社, are comprised of Dan fisherfolk. Relocation of the fishing port will have far-reaching consequences on the fisherfolk's lives and livelihoods.

The plan set forth that Sanya Port should transform from a site of production to a site for tourism. Many social problems lurked behind the triumphalist discourse of urban transformation. The plan to fuel the island's long-term development through international tourism led to a flood of foreign capital and talent, with the result that complex conflicts arose between the interests of local government, developers, and local communities. Marginalised groups located at the edge of the city were particularly vulnerable.

\section{Problematic aspects of port relocation}

As early as 1995, Sanya's municipal government drew up plans to relocate the fishing port from Sanya Port to the Liudao Bay 六道湾 area in order to construct a fully functional and modernised working harbour. Work on this new fishing port began in October 2006, though strategic military concerns required adjustments to the Liudao Bay fishing port plans, and work was halted in August 2007. In August 2008, the Ningyuan River estuary in Yazhou Bay was selected as the new site for the fishing port, and construction work began there in December 2009. The fishing port project required major investments, with an initial injection of 800 million yuan of private capital, eventually increasing to 1.5 billion yuan. The project ambitiously aimed to construct "an integrated fishing port including production operations, logistics, processing, disaster prevention and mitigation, recreational fisheries and tourism services, and other functions" (雷思琦, 2012). The relocation of the fishing port was heralded as a means of completely changing the face of Sanya Port as well as of promoting the marine economy in Sanya and the surrounding region. With the construction of the two other new ports (the International Cruise Terminal on Baipai island and the cargo port in Nanshan), the completion of the Yazhou Central Fishing port has become key to Sanya achieving its long-desired 'separation of three ports'.

The new fishing port is on the west side of the Ningyuan River estuary, between Baogang Village in the east and Yanzao River in the west and backed by the Hainan Island Highway. The government's own report notes: 
The outlet design of the Central Fishing Port had serious technical problems. The direction of departure for the port was perpendicular to the shoreline, with an open river mouth toward the southwest and directly to the sea. In Sanya's summer seasons, wind is mostly from the south and southwest. Yazhou Bay's coastline is on the windward side. Surges pushed from the South China Sea break on the shore. These surges are very large. As long as the wind direction is from south-to-southwest, there will be three-foot high waves even without wind. A port with such an open mouth will be dangerous for fishing boats sailing in and out. [...] No one has identified this problem until now. Looking at the construction of domestic and foreign fishing ports, it is rare to see a vertical angle to the sea (三亚市政协经科委课题组, 2016).

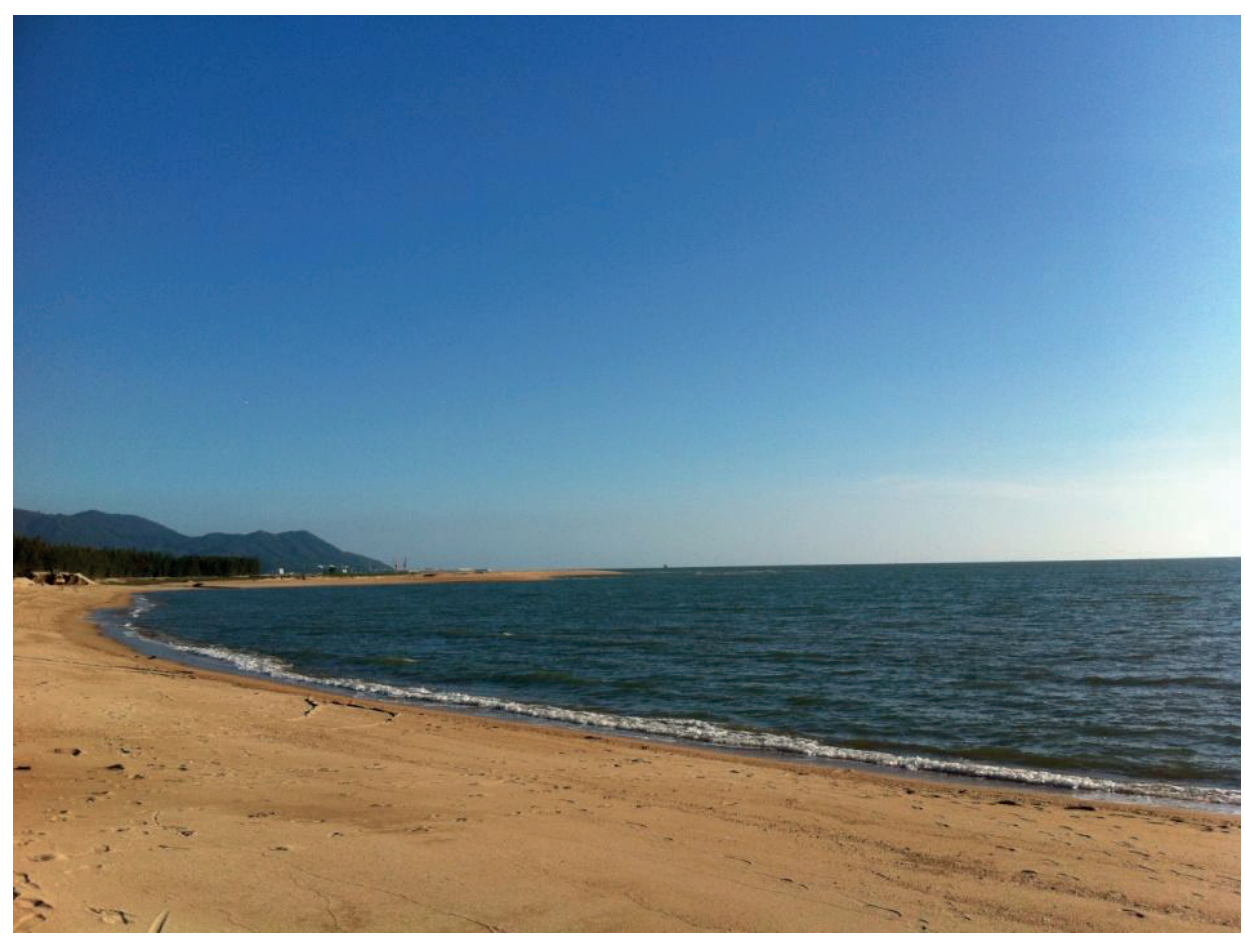

Figure 2: Yazhou Bay (Source: (C) Zuan Ou, 2012).

Field surveys undertaken among the Dan fisherfolk at Yazhou Bay in December 2012 and July 2014 revealed that there had been almost no progress in the construction of the new fishing port over the previous two years (see Figure 2). Captain Liang, a Dan fieldwork contributor, states that the terrain and shape of Yazhou Bay are fundamentally unsuitable for use as a fishing port. Besides the problematic direction of departure, Yazhou Bay is backed by sweeping open space, which provides moored boats with no shelter from the wind. This is in contrast to Sanya Port, which is sheltered by Luhuitou Mountain. Yazhou's seabed is sandy, which prevents anchors from gripping effectively in typhoon conditions, leaving moored boats susceptible to destruction. The traditional knowledge of the Dan, of course, means that they have long been aware of the drawbacks of the port's selected site and design, but their opinions were ignored.

The government wished to renew the city centre even before the new fishing port in Yazhou Bay was complete, and it requested that fisherfolk relocate despite the lack of an alternative harbour. The Sanya Marine Fisheries Service made three attempts to organise a relocation from the old fishing port at Sanya Port to the new (incomplete) fishing port, but all were met with failure. In a January 2016 telephone interview, Captain Liang reported that the Dan had to cope with a number of major production problems. For one thing, after the relocation of the fishing port, production 
costs increased. The fishing grounds are to the south and southeast of Hainan. Captain Liang said:

From Sanya Harbour, it generally takes us four hours to reach the fishing grounds [to the south and southeast of Hainan], sometimes just over three hours, sometimes five hours, but generally four hours. After moving to the fishing harbour at Yazhou Bay, the distance to the fishing grounds increased by 25 nautical miles. Based on our current boat speed, about eight nautical miles per hour, the time increased by about four hours, and the total trip was eight hours. The currents cost us some time, and when we arrived, the fish all swam away, and the extra time cost more oil. (Date: January 2016; Interview Location: Telephone interview; Interviewee: Captain Liang. Translation our own.)

The new fishing port is located around 25 nautical miles from the old fishing port (see Figure 3). When the fishing boats travel between the two, they need to change direction twice: once to navigate around Dongdao island 东岛 and once to get around Nanshan mountain 南山岭. This significantly increases transport times during fishing activities.

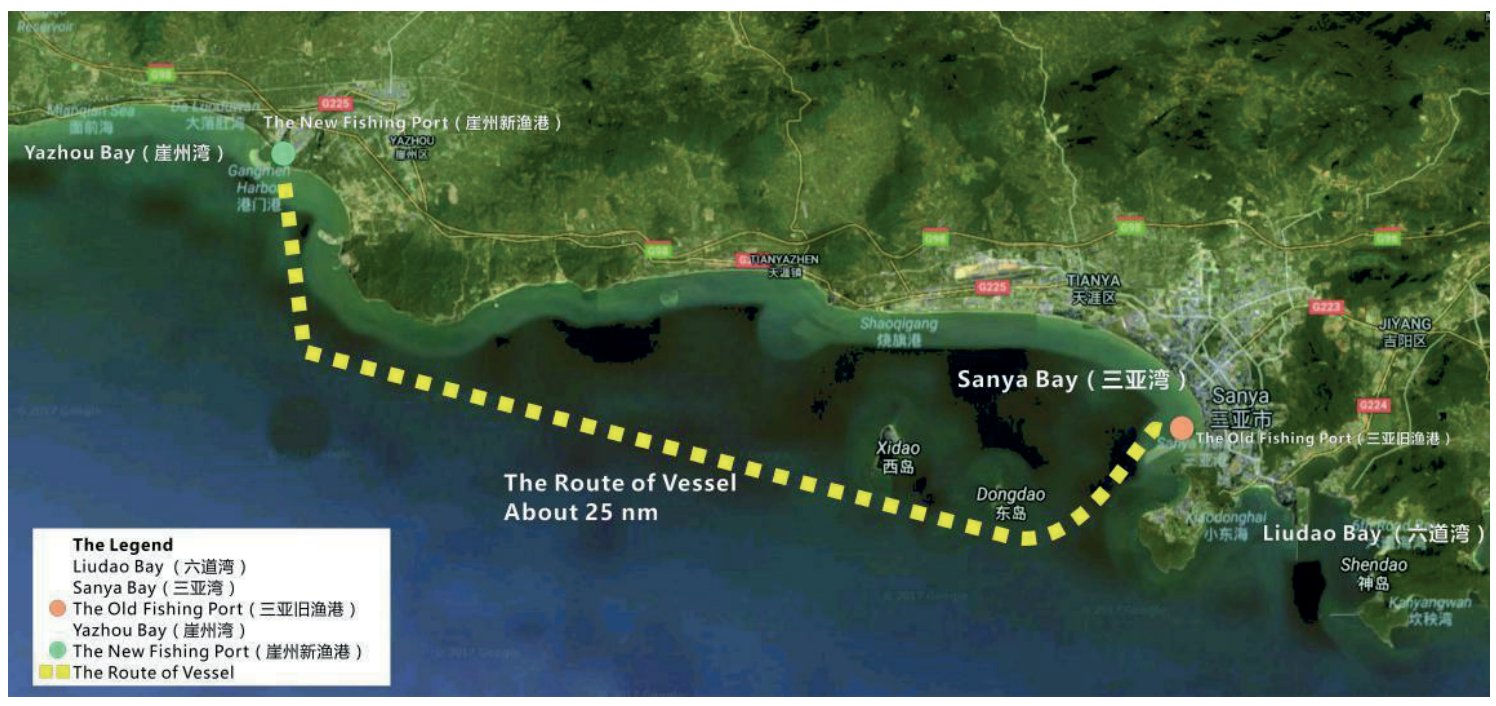

Figure 3: Map of the relocation of Sanya fishing port. (Source: (C) Zuan Ou, 2017).

The more distant port also reduces the freshness of the catch. The fishing boats use ice rather than freezers to keep their catch fresh, with the result that the addition of four hours to the return trip lowers the value of the fish. Captain Liang said:

If the fish were the same price, which one do you think the purchaser would buy? The fish iced for two hours or for four hours? At Sanya Port, you can come back in the morning and sell the fish, then you can get some supplies at noon, and in the afternoon you can go to sea a second time. At night, you could fish. Now after moving to the new fishing port, it is already 14:00 by the time we return to port. After you sell the fish, you do not have time to go to sea a second time. (Date: January 2016; Interview Location: Telephone interview; Interviewee: Captain Liang. Translation our own.)

In addition, subsidies and incentives provided by the government were too low. The first fishermen to relocate were given one-off payments of 30,000 yuan per household. Captain Liang said:

We can pay the government 30,000 yuan annually as a usage fee for the port, as long as we do not relocate. Because the new fishing port is far from the fishing grounds, each 
vessel was subsided with 1,500 yuan per month in 2016. But it was too little money to pay the fuel for an eight-hour voyage every day. (Date: January 2016; Interview Location: Telephone interview; Interviewee: Captain Liang. Translation our own.)

After the old fishing port relocated, many Dan captains felt that Yazhou Bay was too far from home and considered selling their boats and stopping fishing. Captain Liang reported:

This year, people began mobilising against the relocation of the old fishing port. The government set up the fishing port relocation working group and started talking with us. They said that fishing port in Yahzou Bay will be completed soon. They asked us captains to visit the site. Whether we leave home is actually the major factor for relocation. Fishermen who fished in the cooperatives of Nanhai Community did indeed make greater profits because we had relatively large fishing vessels, so we had more catches. Fishermen in Lingao were mainly in favour of redeveloping because their fishing operations were relatively small, and it was easy to meet the demands of production. The western area of Hainan was economically backward with low wages. The developed regions could not find workers. But young people in the backward areas were unwilling to go out because they wanted to stay together with people from the same place. Now there are just over 20 unsold boats in the cooperatives of Nanhai Community. They are used for production. Some people said they wanted to explore Nansha. Actually, it was just about taking the state subsidies and not about making a difference at sea. (Date: May 2016; Interview Location: Telephone interview; Interviewee: Captain Liang. Translation our own.)

Faced with relocation of the fishing port, the Dan had no choice but to follow the current. Their only hope of solving the problems that arose as a result of the port relocation lay with the government. However, the government's focus was on getting the new fishing port established and then gradually resolving the problems later, a clear manifestation of the delaying tactic that plays such a prominent role in today's Chinese social governance.

\section{Further effects of fishing port relocation}

Over the past decades, Sanya City has successfully transformed into an island city for international tourism, and its demand for seafood products for tourists has increased sharply as a result. This has ensured a healthy market for fishery products. Formerly, the Dan sold their catch to buyers, middlemen, or agents at the fishing wharf. Tourists either consumed the products indirectly at restaurants and hotels or purchased the fresh seafood themselves and took it to the city's fish-processing street. Sanya's fishing port, along with the First Market and neighbouring markets, thus formed a complete industrial chain of production, supply, and distribution. Although the Dan once thrived from Sanya's tourism industry, they are now under pressure as a result of its success as high-income tourism displaces traditional industries from the urban waterfront.

Many Dan women and women from elsewhere on the island currently work retail jobs at the old fishing port. After the fishing port relocates, they will lose their place of trade. The relocation will present difficulties for a variety of already marginalised groups. All fishery-related facilities and industrial chains surrounding fishery production (refrigeration plants, ice plants, sea salt shops, fishing gear shops, repair shops, etc.) currently located at the old fishing port in Sanya will be removed and the ground they occupy transformed, with disastrous effects for the city residents they employ. Many of those currently employed at Sanya's fishing port are unwilling or unable to relocate their work to distant Yazhou Bay: Most of the workers live locally in Shuijuxiang or rent inexpensive rooms nearby. 


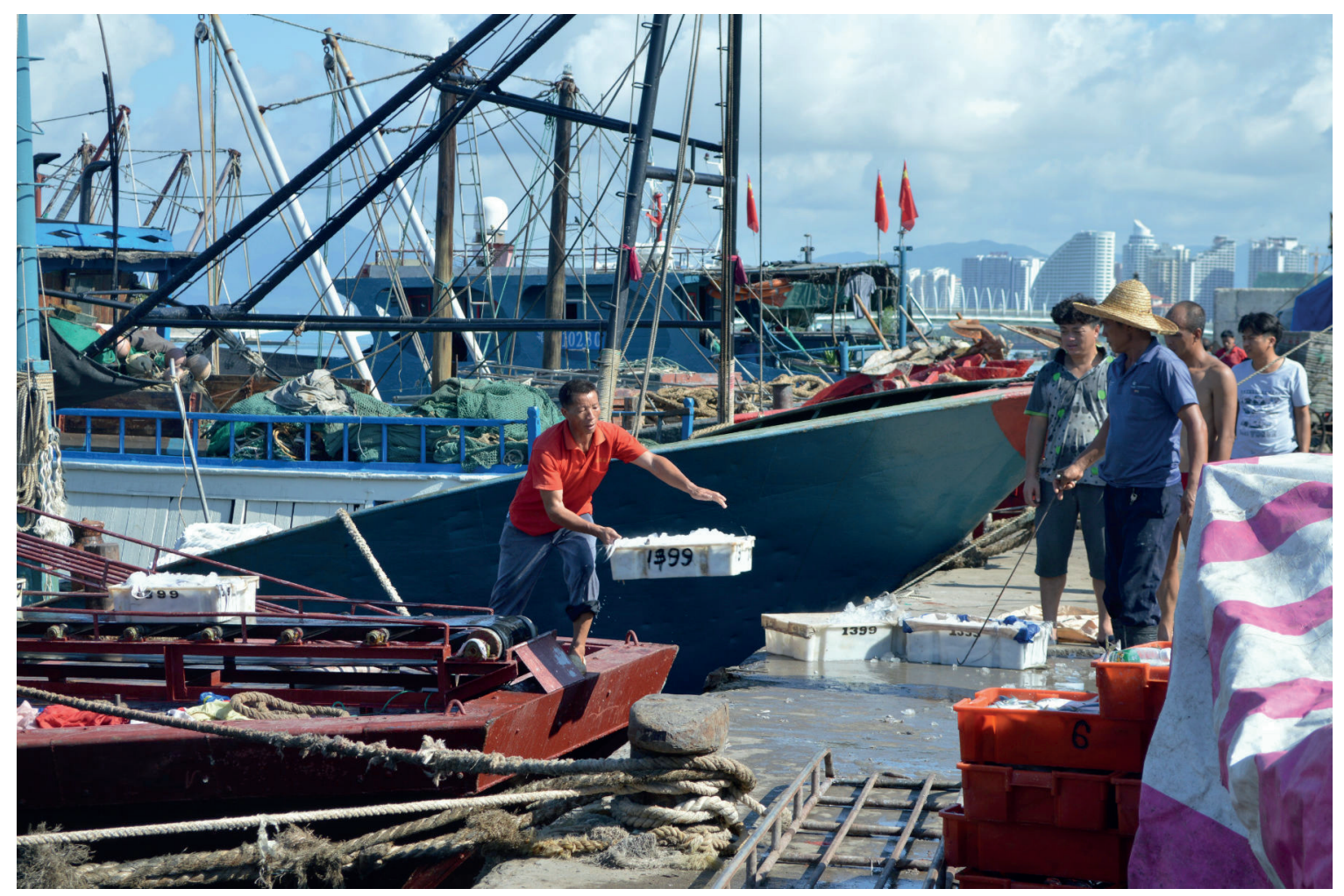

Figure 4: Fishing wharf in Sanya City (Source: (C) Zuan Ou, 2014).

The process of relocating the fishing port, transferring the port functions, and 'renewing' Sanya's city centre places the social security of the Dan at serious risk. For Chinese fisherfolk, there is no system for maintaining minimum standards of living, conditions of production and incomes are deteriorating as the risks and costs of operating a fishing business increase, and elderly fishermen lack guaranteed livelihoods even as the population of fishermen ages (王建友, 2008). These problems all afflict the Dan people of Sanya.

Sanya Port was central to the historical development of Sanya City. If the areas near Sanya Port are all transformed and their residents relocated, future generations will lose their link to the Sanya City's origins. It has thus been suggested that part of the city centre could be set aside as a heritage zone for displaying Sanya's historical development and recording the transition from the seaside fishing village of the past to today's coastal tourism city. Sanya City Planning Bureau has responded to this proposal in a superficially positive manner, supporting the idea of creating a cultural heritage zone to showcase the city's transformation but seeing this in terms of tourism functions rather than in terms of preserving the area's traditional fishery functions and intangible culture heritage.

From the past objective of 'unification of three ports' to today's objective of 'separation of three ports', Sanya Port's fishing functions will soon disappear. Tourism planning and development will take their place and represent the future direction of Sanya Port. As an international tourism city, Sanya needs civilised, clean, and modern port facilities as its windows to the outside world. Nevertheless, it is important that we consider not just Sanya's modernisation but also the lives and livelihoods of those who have for generations made a living from fishing there.

\section{Theories of marginalisation and further marginalisation}

In 1908, Georg Simmel proposed the concept of 'the Stranger', whose position "as a full-fledged member involves both being outside it and confronting it," and who "like the poor and like sundry 'inner enemies' is an element of the group itself." The stranger is "by nature no 'owner of soil'- soil not only in the physical, but also in the figurative sense of a life-substance," and is 
"not radically committed to the unique ingredients and peculiar tendencies of the group" (Simmel, 1950 [1908], p. 402-408). In the 1920s, Robert E. Park, Simmel's student, proposed the concept of 'the marginal man' on the basis his own urban study of Chicago, focusing on the loss of cultural identity due to intermarriage and immigration. Park $(1928$, p. 893) argued that the marginal man is ordinarily "a mixed blood [...] but that is apparently because the man of mixed blood is one who lives in two worlds, in both of which he is more or less of a stranger."

Chinese scholarship has produced nuanced accounts of 'marginalisation', 'group', and 'society', gaining inspiration from but also often diverging from western scholarly tradition. For example, Fei Hsiao-tung (费孝通, 1994) analysed two perspectives on 'society': According to the first perspective, society is comprised of groups, and community is comprised of people who cooperate through a just division of labour. According to the second perspective, society is higher than the group and possesses its own logic and cultural cohesiveness. No matter which perspective one takes, the group level encompasses more than just an ethnic group or a community. A group can be comprised on the basis of blood relations, race, occupation, region, religion, and other conditions.

Chien Chiao advances the concept of 'base and marginalised class', denoting people of low social status on the margins of society (乔健, 2002). This conception is based significantly on Max Weber's (1978) categorisation, which focuses on social stratification inasmuch as most of the base and marginalised class engages in jobs of relatively low social prestige (乔健, 2007). 'Base and marginalised class' is a relative concept inasmuch as the 'base' in question depends on the dominant structures of the agricultural, industrial, or commercial society under consideration. Chiao Chien regards this concept as important for moving beyond Robert Redfield's fixed discussion of the 'great tradition' and the 'little tradition' (e.g. Redfield, 1986 [1960]). Chiao Chien's concept reveals the internal complexities of the 'little tradition' and focuses on marginalised groups at the 'base' and 'margin' of the 'little tradition' (乔健、李菲, 2014). In his conceptual framework, 'serving people' is a general principle of confirming base and marginalized class in traditional Chinese society, except for Dan people. The Dan faced social discrimination in Han society not because they engaged in work with low prestige but because they lived on the water.

Zhou Xiaohong describes two characteristics of the personality of the marginal man: the marginal man is located at the turning point of two social formations or the border of two specific times, and the marginal man is on the boundary of two cultures (周晓虹, 2014, p. 224). Pan Guangdan (潘光旦, 1999) proposes the dual concepts of societal 'order' and 'growth', in which 'order' is static while 'growth' is progressive and dynamic. These two concepts have a mutually dependent relationship and together coordinate the developments and interactions of environments and objects. According to Pan Guangdan (潘光旦, 1999), marginalised groups lack the ability to coordinate their transformation because they exist at the margins of the societal order. They are thus unable to obtain equal opportunities for development while maintaining their social and cultural identities, leading to a situation of further marginalisation in which society progresses without them.

Drawing upon Fei's, Chiao's, Zhou's, and Pan's theories of marginality, we describe two types of marginal groups:

1. Synchronic marginal groups, including both those who live in other cultures because of their studying abroad or immigration and those who live on the edge of the ethnic ecotone in a multi-ethnic country.

2. Diachronic marginal groups, who have difficulty adapting to ideological renewal, structural change, tradition demise, and scientific and technological revolution in periods of social unrest, change, and transformation. These include the farmers, who, in the era of rapid urbanisation, rushed to cities but failed to be accepted by urban life. In modern China, these groups were long referred to as 'migrant workers' (张汝立, 2006). They are diachronic marginal groups during societal transformation. 
Hunter-gatherers may be regarded as a characteristic marginal group. For example, the livelihoods, society, and culture of the Oroqen people of Inner Mongolia have been greatly influenced for over a century by forest development, settlement, and a policy that forbids hunting and transferring assets. They become the "marginalized minority nationality forever" (麻国庆, 2007). Indeed, entrenched perceptions of ethnic otherness can produce systems in which marginality is an inherent aspect of difference (Grydehøj \& Ou, 2017). Marginal status is not always a disadvantage however. For instance, as Peterson (1977) showed, Southeast Asian Negrito hunters benefited from living near farmland, which offered the convenience of trading with agriculturalists and attracting wild game. They lived on the 'edge', between forest and field, a transition zone that ecologists have identified as the ecotone (Peterson, 1977). The ecotone concept has recently been applied within the field of island studies to grasp environmental and societal interactions on the coast (Gillis, 2014; Petzold, 2017). James C. Scott (2009, p.174) argues that self-marginalisation is quite common in certain Southeast Asian contexts, as groups create cultural distance between themselves and society, which "may involve the adoption and maintenance of linguistic differences, of distinctive histories, of differences in attire, burial and marriage rites, housing styles, forms of cultivation, and altitude." As the hill people in Scott's study assert, "We are a nonstate people. We are in the hills swiddening and foraging because we have placed ourselves at a distance from the valley state" (Scott, 2009, p.174). Both the Negrito on the edge of ecotone and self-marginalising hill people are examples of synchronic marginal groups.

Communities of fisherfolk may be particularly likely to suffer from 'further marginalisation', a process in which already marginal groups risk being unable to adapt to wider social transformations and thereby lose out on opportunities for development. Fishing, which formerly represented a complete livelihood, turned into a specific career as a result of technical specialisation. In coastal and insular areas, the living conditions of already-marginalised Chinese fisherfolk have been progressively worsening. Despite advances in fishing technologies, fishing profits have been decreasing for over a decade, and many fisherfolk have fallen into poverty (cf. Nurdin \& Grydehøj, 2014). Rapid fishery development has led to the depletion of fishery resources, at times resulting in extreme policy solutions, such as the government-led relocation of fisherfolk from Kueishan Island in Taiwan (吕美玉, 1996). Some other islands have gradually shifted from functioning as productive fishing ports to serving as tourism fishing ports, with one example being Hsingda harbor in Kaohsiung (庄英章, 1981).

\section{Marginalisation of the Dan}

In China's traditionally agriculture-dominated society, fisherfolk represented a weak and marginalised group. This was especially true for the Dan. Although they were located within the same professional framework as farmers in terms of their societal function as producers of food, fisherfolk were significantly more vulnerable than farmers since they were by definition located on the physical margins of Chinese society, possessing an inward-looking and specifically continental cultural imaginary, with islands in particular representing realms beyond the reach of Chinese civilisation (Luo \& Grydehøj, 2017).

For the Dan of Sanya City, the transformation of Sanya Port represents a very material change in circumstances and cause of further marginalisation. As we have seen, the Dan of Sanya City live on the coast, between mountain and sea. Traditionally, the Dan could easily change location and move long distances. We can term the Dan 'a synchronic marginal group between land and sea'. Unlike China's majority Han society, the Dan have traditionally emphasised mobility and self-marginalised by locating themselves far from state centres. In the South China Sea, it was commonly said in former times that 'the Dan are beyond the control of emperor and take control of the sea' (天高皇帝远, 海阔疍家强). The implication is that Dan did not obey 
the political order of the dynasties and could move freely. They lived on the edge and desired freedom. Imperial institutions found it difficult to govern or even keep track of the Dan. The Dan could easily shift to more advantageous sites on the sea and were not tied to farms and were free of the agricultural calendar and activities. This freedom provided definite advantages for the Dan but also implied a form of marginality relative to China's centre of economic, cultural, and political power. Liang Qichao believed that the Dan were despised because they lived on the water, and it is a commonplace in Chinese society to say that everyone must be attached to the land (梁启超, 1936, p. 10). Land is the starting point for Chinese social relations.

In modern times, particularly following the establishment of the People's Republic of China, the Chinese state defined the Dan as a group in need of assistance because of its marginality. The state helped the Dan move from the water to the land (Grydehøj \& Ou, 2017, pp. 79-80). When the resettled Dan contemplated the differences between their own culture and that of Han, they confronted social transformation. In periods of transformation, people's behaviours, lifestyles, and value systems can change dramatically (李培林, 1992). As a synchronic marginal group, the Dan are today experiencing a transformation from a maritime fishing community to a grounded port society. Although they transitioned from living on boats on the water to living in houses on the land, the Dan retained their maritime habitus. We can view them as 'a diachronic marginal group between land and sea' in the process of social transformation.

As Secretary Chen, former secretary of Yugang community, reported during an interview, prior to 1950, the Dan of Sanya gained their livelihoods from coastal fishing, dwelling aboard their boats, with no permanent place of residence. They relied entirely on the sea. Their tools were simple, and because their catch was difficult to preserve, the Dan people were largely lacking in fixed assets and unable to accumulate capital. During the Japanese occupation, a ban on fishing made life difficult for the Dan people, but after 1950, Yaxian People's Government, which was then responsible for the Sanya area, organised the fisherfolk and established a fishery mutual-aid society. The government successively set up primary fishing cooperatives, senior fishing cooperatives, and people's communes.

In the early 1970s, the secretary of the Revolutionary Committee of Yaxian mobilised the Dan of Sanya to live onshore. The earliest Dan to settle in Sanya built primitive houses on a sandy spit extending out to the north of the Sanya River, then gradually settled on both banks of the river (in reality, an island and a presqu'île/almost-island; see Hayward, 2016) and formed the two communities of Shuijuxiang 水居巷 (literally, 'Street of the Water Dwellers') to the north and Naihaixiang 南边海 (literally, 'Village on the South Sea Shore) to the south. The original buildings were sheds and water fences, built with wood and grass, in some ways replicating the conditions of living aboard boats. The older generation called the neighbourhood the 'Shack of the Dan 疍家棚'. The implication is that the land had not appealed to the Dan before. The Shack of the Dan became the Dan people's transformational construction form from living on water to living on land, from being non-resident to being resident.

Over time, more and more of the formerly mobile Dan settled down ashore, yet most continued to make a living from fishing. The development of Sanya City, however, saw the Shuijuxiang neighbourhood transform from an informally settled fishing village into part of a city centre. Shuijuxiang is near Sanya Bridge, and across the road from Shuijuxiang is the First Market, one of the city's main tourist attractions. Sanya fishing port was just outside the houses' doors, making it easy to sell the day's catch. Residents of Shuijuxiang enjoyed the services and facilities brought about by the development of the city centre. Indeed, those Dan who had never or no longer fished could find work at the market or on the pier. Some fisherfolk even worked on fish farms.

In recent years, the Dan, as a marginalised group, have faced three main difficulties: 1) a growing scarcity of marine resources, followed by plans to redevelop Sanya Port and, in the process, 2) demolish the homes in Shuijuxiang, and 3) relocate the fishing port outside of the city. As the dominant economy of Hainan has shifted from the primary sector to tourism, the Dan have needed to change jobs and transfer assets. This has resulted in the further 
marginalisation of an already marginalised group. Even as their old lifestyle becomes impossible, the Dan struggle to find alternatives. The problems that the Dan face as a result of relocation of the fishing port to Yazhou Bay, as considered above, provide evidence of further marginalisation in action. The Dan fisherfolk —already lacking in social, economic, and political capital-find themselves unable to affect change with regard to or mount a defence of their livelihood. The authorities have ignored their concerns and proposed largely bureaucratic solutions to quite systematic problems with regard to the economics of fishing.

Furthermore, once the relocation of the Sanya's fishing port is complete, the Dan's former neighbourhood will become a haven for wealthy tourists, and the Dan will be scattered across suburban resettlement areas around the city. Uneven development has created a 'dual city' (Mollenkopf \& Castells, 1991) and a widening gap between labour and capital. The Dan who are lacking in education and technical know-how have become superfluous to the new tourism economy. As a traditionally marginalised group, the Dan first coped with changing conditions by moving ashore in the 1970s and 1980s, taking on a settled lifestyle, though without the advantages of traditional terrestrial knowledge and accumulated capital that were possessed by existing non-marginalised land-dwelling groups in the region. Recent plans for Sanya's urban renewal have presented the Dan with further marginalisation through the relocation process.

\section{Conclusions}

How can the Dan confront the combined challenge of losing their homes, losing their boats, losing their fish, and losing the sea? The splitting up and partial relocation of Sanya Port cannot be regarded simply as 'local development'. Sanya must be understood in the context of the massive urbanisation process that is in full swing across China, as large-scale relocations of populations and urban functions clear space for societal development. However, in China's mainland provinces, urban-rural integration represents the key site of conflict while in Sanya, the conflict is between the international tourism city and the community of fisherfolk. Whereas the Chinese mainland must cope with a tension between agricultural and urban lifestyles, the people of Hainan are adapting - or in some cases, failing to adapt - to a redistribution and reconceptualisation of marine resources. The coast and sea have transformed from sites for highly localised primary and secondary sector production to sites for the globalised leisure economy. This represents a clash of cultural values and understandings of marine and land territoriality, as the Dan are pushed to adopt the livelihoods and lifestyles of the majority population (Grydehøj \& Ou, 2017). Human development is the most important aspect of urban development, yet Sanya City's urban renewal process risks losing sight of the city dwellers whose interests such development should be serving.

Prattis (1980) argues that policies to develop marginal regions through increased exposure to modern market forces misunderstand that the existing marginality is itself a result of exposure to the specific structure of modern market forces. The Dan in Sanya are in precisely this predicament. Statistics from 2015 indicate that Sanya's returns from the fishing industry were 1.8 billion yuan (三亚统计信息网, 2016), while tourism revenues in the same year reached 30.2 billion yuan (三亚统计信息网, 2016). This explains the government's efforts to transform Sanya Port. In today's construction of Sanya as an international tourism city, urban demolition is a step in the reconstruction of urban space. This process exposes the Dan of Shuijuxiang to residential relocation and livelihood transformation.

Historically, Hainan's Dan were a marginal group relative to the traditional farming-dominated system of Han society due to their maritime mode of economic production and their water-based, boat-dwelling lifestyle, which discouraged the accumulation of capital. Agricultural society did not inherently threaten the Dan's interests, but the emergence of an island city with a tourismdominated economy has introduced competition for the marine space of the Dan's lives and livelihoods. This marginalised group, which formerly possessed the ability to make and enact its own decisions, has had its independent decision-making power over development removed due to the 
top-down policy of international island tourism. The Dan as a whole lack the capacity to coordinate and adapt to developments in their environment, thereby depriving them of the ability to develop alongside more privileged social groups. In the process of transforming from a synchronic marginal group to a diachronic marginal group, the Dan are facing further marginalisation.

Sanya Port's transformation into a high-end tourism destination is not a development to which the local Dan can contribute. The government has invested a huge quantity of public resources in introducing investment and accelerating development, yet it has failed to face up to demands for social equity. The city should be developed in ways that do not harm local people's quality of life and development opportunities. The government of Sanya City should pay more attention to the legitimate interests and aspirations of marginalised groups in island tourism development.

\section{Project funding}

Funding was provided by the National Social Science Foundation of China for the project: 'A Comparative Study of Social Transformation of the Fishery Societies on Hainan and Taiwan Islands' (project number: 14XMZ085), and by the Education Department of Hainan Province for the general project of scientific research in colleges and universities: 'A Study on Ecological Anthropology of the Hainan Fisherfolk' (project number: HNKY2014-78).

Funding was also provided by the major programme for humanistic and social scientific research in colleges and universities, administered by the Education Department of Guangdong Province for the key project of humanistic and social science research in colleges and universities: 'A Study on Overseas Transmission of Chaoshan Culture: Transnational Network, Ethnic Interaction and Cultural Communication'(project number: 2013ZGXM0001).

\section{References (English)}

Baldacchino, G. (2012). Islands and despots. Commonwealth \& Comparative Politics, 50(1), $103-$ 120. https://doi.org/10.1080/14662043.2012.642119

Baldacchino, G. (2007). Islands as novelty sites. Geographical Review, 97(2), 165-174. https://doi.org/10.1111/j.1931-0846.2007.tb00396.x

Du, M. (2016). China's 'One Belt, One Road' initiative: context, focus, institutions, and implications. Chinese Journal of Global Governance, 2(1), 30-43. https://doi.org/10.1163/23525207-12340014

Gillis, J.R. (2014). Not continents in miniature: islands as ecotones. Island Studies Journal, 9(1), $155-166$.

Grydehøj, A. (2015a). Island city formation and urban island studies. Area, 47(4), 429-435. https://doi.org/10.1111/area.12207

Grydehøj, A. (2015b). Making ground, losing space: land reclamation and urban public space in island cities. Urban Island Studies, 1, 96-117. https://doi.org/10.20958/uis.2015.6

Grydehøj, A., \& Ou, Z. (2017). Deterritorialization of indigeneity: indigenous territory, development policy, and the Dan fishing community of Hainan (China). Political Geography, 61, 77-87. https://doi.org/10.1016/j.polgeo.2017.07.002

Grydehøj, A., Pinya, X.B., Cooke, G., Doratl, N., Elewa, A., Kelman, I., Pugh, J., Schick, L., \& Swaminathan, R. (2015). Returning from the horizon: introducing urban island studies. Urban Island Studies, 1, 1-19. https://doi.org/10.20958/uis.2015.1

Hayward, P. (2016). Introduction: towards an expanded concept of island studies. Shima, 10(1), 1-7. https://doi.org/10.21463/shima.10.1.03

Hong, G. (2017). Locating Zhuhai between land and sea: a relational production of Zhuhai, China, as an island city. Island Studies Journal, 12(2). https://doi.org/10.24043/isj.16

Mollenkopf, J.H., \& Castells, M. (Eds.) (1991). Dual city: restructuring New York. New York: Russell Sage. 
Nurdin, N., \& Grydehøj, A. (2014). Informal governance through patron-client relationships and destructive fishing in Spermonde Archipelago, Indonesia. Journal of Marine and Island Cultures, 3(2), 54-59. https://doi.org/10.1016/j.imic.2014.11.003

Park, R.E. (1928). Human migration and the marginal man. American Journal of Sociology, 33(6), 881-893. https://doi.org/10.1086/214592

Peterson, J.T. (1977). The merits of margins. In W. Wood (Ed.), Cultural-ecological Perspectives on Southeast Asia: a symposium (pp. 63-73). Athens, OH: Ohio University Center for International Studies.

Petzold, J. (2017). Social adaptability in ecotones: sea-level rise and climate change adaptation in Flushing and the Isles of Scilly, UK. Island Studies Journal, 13(1). https://doi.org/10.24043/isj.17

Prattis, J.I. (1980). Modernization and modes of production in the North Atlantic: a critique of policy formation for the development of marginal maritime communities. American Journal of Economic and Sociology, 39(4), 305-319. https://doi.org/10.1111/j.1536-7150.1980.tb01282.x

Redfield, R. (1986 [1960]). The little community and peasant society and culture. Chicago \& London: University of Chicago Press.

Sheng, N., Tang, U.W., \& Grydehøj, A. (2017). Urban morphology and urban fragmentation in Macau, China: island city development in the Pearl River Delta megacity region. Island Studies Journal, 12(2). https://doi.org/10.24043/isj.25

Simmel, G. (1950 [1908]). The sociology of Georg Simmel. K. Wolff (Trans.). Glencoe, IL: The Free Press.

Scott, J.C. (2009). The art of not being governed: an anarchist history of upland Southeast Asia. Yale: Yale University Press.

Wang, J., \& Liu, Y. (2013). Tourism-led land-use changes and their environmental effects in the Southern Coastal Region of Hainan Island, China. Journal of Coastal Research, 29(5), 1118-1125. https://doi.org/10.2112/JCOASTRES-D-12-00039.1

Weber, M. (1978) Economy and society: an outline of interpretative sociology. In G. Roth \& C. Wittich (Eds.). Berkeley: University of California Press.

Zhang, X., Wang, Y., Qi, Y., Wu, J., Liao, W., Shui, W., Zhang, Y., Deng, S., Peng, H., Yu, X., \& Qi, H. (2016). Evaluating the trends of China's ecological civilization construction using a novel indicator system. Journal of Cleaner Production, 133(1),910-923. https://doi.org/10.1016/j.jclepro.2016.06.034

\section{References (Chinese)}

陈永锭. 《高雄市旗津亲水观光发展之政策研究》 [D], 高雄海洋科技大学渔业生产与 管理系硕士论文，2013年。

费孝通. 《个人・群体・社会一—

一生学术历程的自我思考》 [J]，《北京大学学报（哲学社会科学版）》，1994 年第1期。

海口市统计信息网. 《海口市2010第六次人口普查主要数据公报》 [EB], http://www. h kstats.gov.cn/tjpc/rkpcgb/201303/t20130321 571364.html。

海南省政府. 《2015年海南省政府工作报告》 [EB], 《海南日报》，2015年2月10日， http://hnrb. hinews. cn/html/2015-02/10/content 2 2.htm。

黄向春. 《从疍民研究看中国民族史与族群研究的百年探索》

$[J] ， 《 广$ 西民族研究》，2008年第4期。

雷思琦. 《三亚斥资15亿建设崖州中心渔港》［EB]. 海南省财政厅，2012年4月19日. http://mof. hainan. gov. cn/news/read.php?ID=153708。

李培林. 《另一只看不见的手: 社会结构转型》 [J]. 《中国社会科学》, 1992年第 5 期。 
梁启超. 《中国历史上民族之观察》，《饮冰室专集之四十一》 [M]，中华书局，193 6年。

吕美玉. 《龟山岛的人口迁移与环境调适之研究》 $[D]$, 台湾: 台湾中国文化大学地理 学研究所, 1996年。

麻国庆.

《开发、国家政策与狩猎采集民社会的生态与生计 以中国东北大小兴安岭地区的鄂伦春族为例》 $[J], 《$ 学海》，2007年第 1 期。 麻国庆. 《海南岛: 中国人类学研究的实验室》 $[\mathrm{J}]$, 《广西民族大学学报（哲学社会 科学版）》，2014年第5期。

潘光旦. 《尚同与尚异》 [1933]，见《潘光旦文集》 $[M]$ （第2卷），北京大学出版社， 1999年。

潘光旦. 《演化论与几个当代的问题》 [1947]，见《潘光旦文集》 [M]（第5卷），北京 大学出版社，1999年。

乔健. 《谈中国研究的一些方法论问题》 $[\mathrm{J}]$, 《广西民族学院学报（哲学社会科学版 ）》，2002年第4期。

乔健. 《绪论: 底边阶级、边缘社会与阈界社会》，见乔健编著: 《底边阶级与边缘社 会一一传统与现代》 [M]，台湾立绪文化事业有限公司，2007年，第14-33页。

乔健、李菲. 《乔健口述史》 [M]，云南人民出版社，2014年。

容观瓊. 《黎族地区改革的根本出路在于改变人一一〈海南经济发展战略读后〉》

$[\mathrm{A}] ， 《 广$ 东民族研究论从》[C]（第五辑），广东人民出版社，1991年。

三亚市天涯区人民政府. 《关于天涯区海洋捕捞业发展情况报告》 [R]，[2016]80号。

三亚市政协经科委课题组. 《加快渔港搬迁

推动经济发展

我市崖州中心渔港搬迁调研报告》[R]，2016年4月22日。

三亚统计信息网. 《2016年三亚市统计年鉴・3-3全市各区总户数及总人口》 [EB], http://www. systats.gov.cn/tjs.j/tjnj/nj/3/201701/t20170110 2208709. html。

三亚统计信息网. 《2016年三亚市统计年鉴・4-

8农林牧渔业总产值、增加值及物质消耗》 [EB], http://www. systats. gov. cn/t js j/tjnj/nj/4/201701/t20170111_2209299. htm1。

三亚统计信息网。《2016年三亚市统计年鉴・11-

9接待过夜旅游者人数及旅游收入》 $[\mathrm{EB}]$,

http://www. systats. gov.cn/t.js.j/t.jnj/nj/11/201701/t20170119 2216462. html。

三亚新闻网. 三亚港: 明代南海贡道上的贡船寄泊港

[EB], http://www. sanyarb. com. cn/content/2013-01/13/content 63391. htm。

苏轼. 《峻灵王庙铭》 [A]. 《與地纪胜》 [M] (七)，四川大学出版社，2005年。

王建友. 《论海洋社区渔民的社会保障问题》 [J]，《当代经济》，2008年第2期。

杨其元. 《海南天涯海角摩崖石刻》 [M] ，海口南方出版社，2008年。

曾昭璇. 《从人类地理学看海南岛历史上的几个问题

》 $[\mathrm{A}] ， 《 广$ 东民族研究论从》 $[\mathrm{C}]$ （第四辑），广州：广东人民出版社，198 8年。

张汝立. 《农转工：失地农民的劳动与生活》 $[\mathrm{M}]$ ，社会科学文献出版社，2006年。

庄英章.《渔业政策与地区性渔业发展一一兴达乡的田野调查分析

$》[\mathrm{~J}] ， 《$ 台湾中央研究院民族学研究所集刊》，1981年第51期。

周晓虹. 《理论的邂逅——社会学与心理学的路径》 [M], 北京大学出版社, 2014年。 